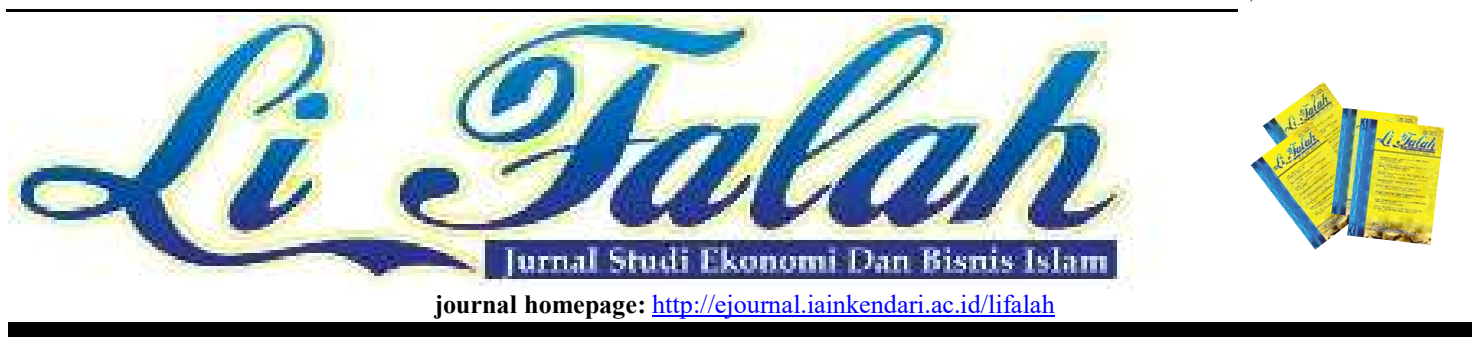

\title{
Contradictive Istinbath Akad Murabahah Law Bil Of Sharia Financing Time
}

\section{Nurhadi}

Sekolah Tinggia Agama Islam (STAI) Al-Azhar Pekanbaru Riau Email: alhadijurnal@gmail.com; alhadicentre@yahoo.co.id

\section{INFO ARTIKEL}

Keywords: Contradictory, Istinbath, Law, Contract, Murabahah Bil Wakalah.

DOI:

http://dx.doi.org/10.31332/lifalah.v4i2.1518

\section{A. Introduction}

The idea of establishing Islamic banks in Indonesia had actually emerged

\section{A B S T R A K \\ Abstract}

A contract is a written agreement between a Sharia Bank or a Sharia Business Unit and another party that contains the obligation for parties in accordance with sharia principles, this is a definition according to the Sharia Banking Law. A contract is a legal relationship between parties that creates rights and obligations that are exchanged by the parties. An agreement is an event someone promises to another person or somewhere two people promise to do something or plan. All three are equated in the concept of business law engagement. The difference between the agreement and the contract according to the science of jurisprudence, the agreement is different from the agreement according to business law, but the difference is only in the term of use. By law and sharia, the murabahah and wakalah contracts are legalized. But if the murabahah bil wakalah agreement is not clear between the two contracts which one is used, there is obscurity (gharar), the law is haraam. But if the two contracts can be clear (not gharar) and separate (which one is the right one), then a transaction with two contracts is permitted, for example murabahah bil wakalah transaction, by means of the wakalah contract, then the murabahah contract, then this contract is enforced.

since the mid-1970s. This was discussed at a national seminar on Relations between Indonesia and the Middle East in 1974 and in 1976 in an international seminar 
organized by the Institute for Social Sciences Studies (LSIK) and Yayasan Bhineka Tunggal Ika.

Until now, Islamic banking financial institutions in Indonesia have shown significant development over the past several years, as evidenced by the emergence of conventional Sharia Banking Business Units, as well as branch offices and supporting offices of PS and UUS. That is because some Muslim communities want a banking system that is free of usury.

The function of Islamic banking institutions besides being an intermediary institution also as an investment institution that is very instrumental in supporting the economic growth of a nation. In addition, the role of Islamic banking as a support of business decisions is the need of the community to carry out an economic activity.

The characteristics of the Islamic banking system that operate based on sharia principles provide an alternative in production to avoid speculative activities in financial transactions.

Various financing which is channeled by Sharia Banking, for customers to open up business opportunities and work that is increasingly widespread. Besides that, it can also foster Islamic brotherhood through economic activities in order to increase per capita income towards a better quality of life by providing financing that can ease the burden on the community. Some of them choose murabahah financing because the financing is considered as an easy means to assist the procurement of goods and services that are used both for business activities and for investment.

The most dominant sharia banking product offered in financing is murabahah financing, which is the sale and purchase of goods at the original price with an agreed additional profit. In murabahah, the seller must tell the price of the product purchased and determine a level of profit in addition. There is another understanding that explains that murabahah is buying and selling on the basis of the information from the seller related to the cost of purchase and the desired level of profit. Murabahah is one form of trustworthy sale (on the basis of trust).

From this background, the author would like to discuss what is actually the nature of aqad in law and shari'a and how is the law of two contracts in one contract in the murabahah bil wakalah contract in Islamic finance?

\section{B. Sharia Financing}

So much Islamic finance, the most central is Islamic banking. Sharia banking is everything that concerns Sharia Banks and Sharia Business Units, including institutions, business activities, and ways and processes in carrying out their business activities.

Technically juridical, it must be distinguished between the terms of Islamic Banking and Islamic Banks. Sharia Banks are part of Sharia Banking other than Sharia Business Units (UUS), while Sharia Banks consist of Sharia Commercial Banks and Sharia Rural Financing Banks (BPRS). In Law Number 10 of 1998 distinguishes banks based on their business activities into two, namely conventional banks and banks with sharia principles, namely Islamic Law in banking activities based on the fatwa of institutions that have authority in establishing fatwas in sharia banking, namely the National Sharia Council of the Ulema Council Indonesia (DSN-MUI). The explanation is in Article 1 paragraph 2 and in article 1 paragraph 7. It is stated in article 1 paragraph 2 that banks are business entities that collect funds from the public in the form of loans and / or other forms in order to improve people's lives. Whereas in Article 1 paragraph 7 states that the definition of Islamic banks is a bank that runs its business activities based on sharia principles and according to its type consists of Islamic commercial banks and Islamic finance banks. 
According to Bank Indonesia regulation Number 2/8 / PBI / 200, article 1 , a Sharia Bank is a commercial bank as referred to in Act Number 7 of 1992 concerning Banking and has been amended by Act Number 10 of 1998 which conducts business activities based on sharia principles, including sharia business units and foreign bank branch offices that conduct business activities based on sharia principles.

In general, the special feature of Islamic banks is that the main source of the provisions comes from Islamic law. In terms of sources of profit, the profits earned by Islamic banks do not originate from interest charged to customers, but from what is referred to as compensation, both in the form of services (fee-base income) and mark-ups or profit margins, and profit sharing ( loss and profit sharing). Other special characteristics of Islamic banks in addition to the involvement of Islamic law and the release of interest-based transactions (interest free), are allowed to conduct business activities that are multi-finance and trading (trading). This is related to the nature of Islamic bank transactions which are investments and buying and selling as well as the very diverse implementation of financing that can be done.

Islamic banks are banks that carry out all activities based on sharia principles. Islamic banking began in Egypt in the 1960s and operated as a rural social bank (a kind of village unit financial institution in Indonesia) along the Nile Delta. Institutions under the name Mit Ghamr Bank are guided by Prof. Dr. Ahmad Najjar only operates in rural Egypt and is small scale, but the institution is able to become a very significant trigger for the development of the Islamic financial and economic system.

\section{Credit and Financing}

The word credit comes from the word credere, which means trust, meaning that if someone gets credit, it means they get trust. Meanwhile, for the lender, it means giving someone the confidence that the money loaned will return, the recipient of the credit has the right to use the loan for profit with the obligation to return the loan amount behind the day.

According to Law No. 10 of 1998 concerning Banking states that credit is the provision of money or bills that can be equated with it, based on an agreement or agreement between a bank loan and another party that requires the borrower to repay the debt after a certain period of time with interest.

Bank credit is a process when the bank places a certain amount of funds on its customers to be used in agreement that the funds must be returned along with the interest at the time specified.

In Islam Credit or qardh in Islam is the responsibility that must be paid by the debtor to the creditor in accordance with the loan principal at a certain tempo. Qardh comes from Arabic قرض which means lending money on the basis of trust, which is adopted in the conventional economy and becomes the word credit (Credo). Which has the same meaning, namely loans on the basis of trust.

The term Credit comes from Latin, namely credere which means trust, or credo, which means I believe, meaning the trust of the creditor (lending) that the debtor (the recipient of the loan) will return the loan along with the interest according to the agreement between the two parties.

While financing comes from the word finance, which means finance and becomes the word financing (verb) which means financing. In terms of terms Financing (financing) is funding provided by a party to another party to support the investment that has been planned, both carried out alone or by the institution. Financing in the form of business activities which include financing under the principle of buying and selling (murabahah, salam, istishna), financing under the lease principle ijarah (pure rent) 
and ijarah Muntahiya bittamlik (rent purchase). financing with the principle of profit sharing (musyarakah, mudharabah), complementary contract namely alkafalah, al-hawalah, al-wakalah, al-qardh and ar-rahn.

Extensive financing means spending, namely funding that is spent to support planned investments both among themselves and others. According to its nature, financing is divided into two, namely productive financing and consumer financing. Productive financing is financing aimed at production needs in the broadest sense, namely to increase business both in trade and investment. Consumptive financing, namely financing used to meet consumption needs that will be used up for needs.

According to the Act Number. 7 of 1992 concerning banking as an amendment to Act Number. 10 of 1998 concerning banking in article 1 number (12): "financing based on sharia principles is the provision of money or equivalent claims based on an agreement or agreement between the bank and another party requiring the financed party to return the money or bill after a period of time certain with rewards or profit sharing ". And number (13): "Sharia principles are agreements based on Islamic law between banks and other parties for depositing funds and / or financing business activities, or other activities declared in accordance with sharia, including financing based on profit sharing principles (mudharabah), financing based on the principle of equity participation (musyarakah), the principle of buying and selling goods by obtaining profit (murabahah), or financing capital goods based on the principle of pure rent without choice (ijarah), or by the option of transferring ownership of goods leased from the bank by another party (ijarah wa iqtina)".

According to the Act Number. 21 of 2008, financing is the provision of funds or bills equivalent to it in the form of: a) Profit sharing transactions in the form of mudharabah and musyarakah;

b) Lease transactions in the form of ijarah or lease purchase in the form of ijarah muntahiya bittamlik;

c) Buying and selling transactions in the form of murabahah, salam, and istishna accounts';

d) Lending and borrowing transactions in the form of qardh receivables;

e) Service lease transactions in the form of ijarah for multi-purpose transactions.

All of them are based on an agreement or agreement between a Sharia Bank and / or UUS and other parties requiring parties to be financed and / or given a fund facility to repay the fund after a certain period of time in return for ujrah, without compensation, or profit sharing.

\section{Research method}

This type of research is included in qualitative research, because the nature of the data to be collected is qualitative. Therefore research data is naturalist by using inductive logic and reporting is descriptive. This research focuses on library research or text studies. So this study will focus more on the studies of the text, and include the type of qualitative research. Library research is done because the data sources, both primary (resources) and supporters (secondary resources) are all text.

\section{E. Discussion}

\section{The nature of the contract, contract and agreement \\ Muamalat Islamic Jurisprudence} distinguishes between Wa'ad and contract. Wa'ad is a promise between one party to another, while a contract is a contract between two parties. It only binds one party, that is, the party that gives the promise is obliged to carry out its obligations. Definition of the contract legally can be equated with the agreement. 
Whereas the party that is given the promise does not bear any obligation to the other party. In wa'ad, the terms and conditions have not been defined in detail and specific (not yet well defined). If the party that promises cannot fulfill its promise, the sanctions received are more moral sanctions. In the contract, the party that does not carry out the contract will be subject to sanctions according to those stipulated in the contract.

According to C. Asser contract is a legal relationship between the parties, which gives rise to rights (achievements) and obligations (counter-achievements) that are exchanged by the parties. According to Agus Yudha Hernoko, there are 4 (four) elements of the contract, namely:

1) Legal Relations, meaning that the contract referred to here is a form of legal relationship that gives rise to legal consequences;

2) Wealth Assets, meaning in accordance with the place of contractual arrangement in Book III BW which is included in the systematics of Wealth Law (Vermogensrecht), the relationship established between the parties is wealth-oriented;

3) Parties, meaning that in the legal relationship it involves parties as legal subjects.

4) Achievement, meaning that the legal relationship gives birth to obligations (achievements) to the parties (achievements and counterachievements), which in certain conditions can be forced to fulfill them, even if needed using State tools.

Contract law is regulated in Book III of the Civil Code, which consists of 18 chapters and 631 articles. Starting from Article 1233 of the Civil Code to Article 1864 KUH Perdata / BW.

The definition of a positive legal perspective agreement is a relationship between the law of wealth / property between two or more people who gives the power of the right to a party to obtain an achievement as well as an obligation on the other party to perform an achievement. An agreement is an event where someone promises to another person or somewhere the two people promise each other to do something or plan. According to article 1313 of the Civil Code, an agreement is an act by which one party or more ties itself to one or more people. In article 1340 the Civil Code determines that the agreement only applies between the parties who made it. The agreement cannot bring loss to third parties and third parties benefit because of the agreement.

Setiawan considers that the formulation of Article $1313 \mathrm{BW}$ is not only incomplete but is too broad. It is considered incomplete because it only mentions unilateral agreement. It is called very broad because the word "deed" also includes voluntary representation and unlawful acts. Therefore, Setiawan proposed the formulation to be "an agreement is a legal act, where one person or more ties himself or ties himself to one or more people.

From an agreement arises a relationship between one party and another party called an engagement. An engagement is a legal relationship between two charcoal or more based on the one party's right to the other party, and vice versa the other party is obliged to the party agreed.

In the study, the word engagement has a broader meaning than the agreement, because in book III of the Civil Code, it is also regulated about legal relations which do not originate from an agreement or agreement, namely an agreement that arises from an illegal act (onrechmatige daad) and subject matter agreements arising from the management of the interests of others not based on agreement (zaakwaarneming).

According to understanding, the definition and terminology between the terms contract, contract, agreement and 
engagement, the similarities and differences in the laws of engagement are:

1) In the study of agreement fiqh is different from contract.

2) In the study of business law the Engagement is different from the agreement.

3) Juridically the study of agreement fiqh can be equated with a contract.

4) According to BW the contract is the same as the Engagement.

5) According to $\mathrm{Bw}$ the Agreement is the same as the contract.

6) According to KBBI the contract is the same as the agreement.

Then the similarities between contracts, contracts and agreements are both concepts in the law of engagement. The difference is only in terms and usage in accordance with the real situation. This is also a difference of opinion and understanding among experts in contracts, contracts and agreements in the science of engagement. Although the substance is almost the same even equalized. In substance the four concepts are different:

1) A contract is an obedient consent that binds two world-born and spiritual parties and akhirat.

2) Contract is a bond between two parties in a certain extent (world / birth).

3) Agreement is a limited two-party bond to the one who promises, both birth and the heart, both the world and the hereafter.

4) Engagement is a two-party relationship that ties together in an engagement.

Language has similarities:

1) A contract is Arabic or a syariah language, the purpose of which is the rights and obligations of the contract.

2) Contracts are English (in BW) or Dutch or German are adopted into Indonesian, with the purpose of the rights and obligations of the contractual consequences.
3) Agreement is a definition of another language contract, what is meant is a written contract is an agreement, the purpose of which is the rights and obligations of the agreement.

4) Engagement is a simplification of the language of the contract, this is in accordance with Subekti's opinion, whose objectives are the rights and obligations of the agreement in the agreement.

So the equation of the four concepts is the emergence and emergence of rights and obligations between the two parties who are religious, contracted, promised and committed. So that both have a very close relationship, which is bound in the agreement, contract, contract and agreement.

\section{Istinbath Law of halal Muradah Agreement}

In general, the halal ness of the transaction murabahah is associated with the following verses and hadith: namely ayat al-Qur'an surah Al-Baqarah verse 275 which means: "Allah has justified buying and selling and prohibiting usury". And Al-Baqarah verse 280 which means: "And if (the debtor) is in trouble, then give respite until he is in the field". And surah An-Nisa verse 29 which means: "O ye who believe, do not eat each other's treasures with the path of the heart, except by the way of commerce that applies voluntarily among you". And also surah Al-Maidah verse 1 which means: "O you who believe! Fill the contracts ... ".

Then the Prophet's hadith in the history of Abu Said Al-khurdi that the Messenger of Allah said "Indeed, buying and selling must be done like you like" (HR. Al-Baihaqi and Ibnu Majah, and judged to be authentic by Ibnu Hibban).Ibn Majah's hadith narrated, 'There are three things that contain blessings: buying and selling not in cash, muqaradhah (mudharabah), and mixing wheat with millet for household use, not for sale. (HR. 
Ibnu Majah). Tirmizi's Hadith Prophet said: "Peace can be done among Muslims except peace that forbids the lawful or justifies the forbidden; and the Muslims are bound by their conditions except the conditions that forbid the lawful or justify the forbidden " (HR. Tirmizi). Also the hadith of the Prophet history Nisa'i, Abu Dawud, Ibnu Majah, and Ahmad said, "Deferring (payments) made by people can justify self-esteem and sanction him". And the hadith of the Prophet's history of Abd Al-Raziq from Zaid bin Aslam, Rasulullah Saw was asked about Urbun (down payment) in buying and selling, then he justified it.

While from Jumhur Ijma 'ulama about the ability to buy and sell by way of Murabahah. Based on kedah fiqih: "Basically, all forms of muamalah can be done unless there is a proposition that forbids them."

\section{Istinbath of the Law of the Halal of the Contract of Wakalah}

In general the halal transaki wakalah is associated with the following verses and hadith: namely al-Qur'an surah Al-Kahf verse 19 which means: "And thus we raised them to ask one another among themselves. One of them said: 'How long have you been here (here)?' They replied: 'We have been (here) one or half days.' Said (another): 'Lord you know how long you are (here). So tell one of you to go to the city with your silver money, and let him see which food is better, so let him bring the food to you, and let him behave meekly, and do not even tell your thing to anyone. And Surah Yusuf verse 55 which means: "Make me the treasurer of the country (Egypt). Actually I am a person who is good at maintaining more experience. " And surah al-Baqarah verse 283 which means: "... So, if some of you trust some of the others, let those who believe believe fulfill their mandate and let them fear Allah Allah ...". As well as alMa'idah verse 2 which means: "And please help in (doing) virtue and piety, and do not help in (working on) sin and transgression."

Then the Prophet's hadith in the history of the Imam Muhammad "the Messenger of Allah represented to Abu Rafi 'and an Ansar to marry (qabul the marriage of the Prophet with) Maimunah R.a." (HR. Malik). and Bukhari's history from Abu Hurairah: "A man came to the Prophet to collect a debt to him in a crude manner, so that the friends intended to" handle it ". He said, "Leave it, because the right owner has the right to speak; then said,' Give (pay) this person a year-old camel like his (owed) camel. ' They answered, "We don't get it except the older ones." The Messenger of Allah then said: "Give it to him. Indeed the best of you is the best person in paying. " (HR. Bukhari). Also in the Tirmidhi history of "Amr bin" Auf: "Peace can be done among Muslims except peace which forbids the lawful or justifies the forbidden; and the Muslims are bound by their conditions except the conditions that forbid the lawful or justify the forbidden (HR. Tirmizi).

Jumhur Ijma 'Muslim cleric about wakalah permits, even sees it as a sunnah, because it belongs to the type of ta'awun (help) on the basis of kindness and piety, which is by the Qur'an and hadith. Also the rules of fiqh: "Basically, all forms of muamalah can be done unless there is a proposition that forbids them."

\section{Contradictions of the Murabahah bil Wakalah Agreement}

The location is prohibited if it is associated with one transaction with two contracts or two in one is a condition where a transaction is contained by two contracts at the same time with the same object, the same actor and the same time period resulting in uncertainty (gharar) regarding which contract to used (applicable). This model is called baiataini $f i$ baiah. In the Prophet's Hadith it is clearly stated that three forms of multicontract are prohibited, namely multi- 
contract in buying and selling (ba'i) and loans, two sale and purchase agreements in one sale and purchase agreement and two transactions in one transaction. In a hadith mentioned which means: "The Messenger of Allah forbade the sale and purchase of loans. (HR. Ahmad, Nasa'i, Tirmizi and Ibnu Hibban).

A contract is stated as long as the object, price, and time are known by both parties. If one of them is unclear, then the law of the contract is prohibited. Ibn Qayyim argued that the Prophet prohibited the multi-contract between the salaf contract (giving a loan / qardh) and buying and selling, even though the two contracts if they were applied individually could be allowed. Prohibition of collecting salaf and buying and selling in one contract to avoid falling into the forbidden usury. This happened because someone loaned (qardh) a thousand, then sold items worth eight hundred at a price of one thousand. He seemed to give a thousand and items worth eight hundred to get paid two thousand. Here he gained an extra two hundred.

In addition to the two in one between the salaf and the sale and purchase that is forbidden, scholars also agreed to ban two in one between various buying and selling and qardh in one transaction. All contracts that contain elements of buying and selling are prohibited from being collected with qardh in one transaction, such as between ijarah and qardh, greetings and qardh, sharf and qardh, and so on. Although the combination of qardh and buying and selling is prohibited, according to al'Imrani it is not always prohibited. The collection of these two contracts is permitted if there are no conditions in them and there is no purpose to cover the price through qardh. Like someone who gives a loan to someone else, then some time later he sells something to him even though he is still in the qardh period. That is what the law may be. While the prohibition on the collection of two sale and purchase agreements in a sale and purchase agreement is based on the Prophet's hadith which reads: "From Abu Hurairah, said:" Rasulullah s.a.w. prohibit two buying and selling in one sale and purchase". (HR Malik).

From some of the opinions of the ulama above, the opinion that is unfortunate in this matter is the opinion which says that such contracts give rise to price obscurity and plunge usury. In essence, there is no sale and purchase agreement in the transaction.

Every two in one that delivers to the illegitimate, like ribâ, the law is haram, even though the contracts that build it are permissible. Collection of a number of contracts whose original law may be brought to those prohibited causes the law to be prohibited.

However, from the discussion above, it can be concluded that the multicontract transaction is basically closely related to the terms and contracts included in the transaction, so the validity of each multi-contract transaction will depend on the validity of the terms and contracts included with it. If the terms and contracts contained in the transaction are valid in Shari'a, the multi-contract transaction can be said to be legitimate in Shari'a, but if the terms and contracts contained therein are not valid in the Shari'ah then the transaction cannot be said to be valid. Although Ibnu Qayyim in this case still does not allow one transaction with two contracts.

\section{The mechanism of halal Murabahah bil Wakalah contract}

The legal status of two in one is not necessarily the same as the legal status of the contracts that build it. For example, the bai 'and salaf contract which is clearly stated to be prohibited by the Prophet Saw, but if the two contracts stand alone, then both the bai' and the salaf are allowed. That is, the law of multi-contract cannot be merely seen from the laws of the contracts that build it. It could be that covenants that 
builds it is permissible when it stands alone, but it becomes unclean when the contracts are collected in one transaction. For example murabahah contract and wakalah contract in Islamic banking. In banking practices there are several types of murabahah applications which can all be divided into three broad categories, namely:

1) The type of application of murabahah is a type consistent with muamalah fiqh. In this type the bank buys the goods to be purchased by the customer first after the previous agreement. After the item is purchased on behalf of the bank, it is then sold to the customer at the acquisition price plus profit margin as agreed. Purchases can be made in cash (cash), or tough in the form of installments or at a certain time. In general, customers pay formally.

2) Type is similar to the first type, but the transfer of ownership directly from the supplier to the customer, while the payment is made directly to the first seller / supplier. The customer as the final buyer receives the goods after previously making a murabahah agreement with the bank. Purchases can be made in cash (cash), or tough in the form of installments or at a certain time. In general, customers pay formally. This transaction is closer to the original murabahah, but is prone to legal problems. In some cases it was found that there were claims by customers that they did not owe the bank, but to the third party who sent the goods. Even though the customer has signed a murabahah agreement with the bank, this agreement lacks legal force because there is no proof that the customer receives money from the bank as proof of loan / debt. To avoid such incidents, when the Islamic bank and the customer have agreed to make a murabahah transaction, the bank will transfer the payment of goods to the customer's account (overlap) then debited with the customer's agreement to be transferred to the supplier's account. In this way, there is evidence that funds have been transferred to the customer's account. However, from a sharia perspective the murabahah model is still likely to violate sharia provisions if the bank as the first buyer never receives goods (qabdh) in its name but directly on behalf of the customer. Because in sharia principles the contract of sale of murabahah must be done after the goods, in principle, belong to the bank.

3) The type most practiced by Islamic banks. The bank conducts murabahah agreements with customers, and at the same time represents (wakalah contract) to the customer to buy the goods to be bought for themselves. Past funds are credited to the customer's account and the customer signs the money receipt. This money receipt is the basis for banks to avoid claims that customers do not owe the bank because they do not accept money as a means of lending. This third type can violate sharia provisions if the bank represents customers to buy goods from third parties, while the murabahah sale and purchase contract has been carried out before the goods, in principle, belong to the bank.

Through Bank Indonesia Regulation (PBI) Number 9/19 / PBI / 2007 and BI Circular Letter No. 10/14 / $\mathrm{DPbS}$ dated March 17, 2008 which abolished the enactment of PBI Number 7/46 / PBI / 2005 concerning the collection and distribution of funds of Banks that Implement Business Activities Based on 
Sharia Principles, the implementation of murabahah financing increasingly placed Islamic banks as intermediary institutions acting as a provider of funds not a murabahah seller. This is confirmed in the text of Circular No. BI. 10/14 / DPbS in point III that "the Bank acts as the provider of funds in order to buy goods related to murabahah transaction activities with customers as the buyer of goods". Seeing from the text of this circular letter, it is clear that there is an attempt by Bank Indonesia to affirm that Islamic banking transactions based on the principle of murabahah buying and selling remain financing as other transactions using mudharabah, musyarakah, salam, istishna, ijarah, and ijarah muntahiya bit tamlik contracts.

Murabahah bil Wakalah is based on the Fatwa of the National Sharia Council No: 04 / DSN-MUI / IV / 2000, that is, if the bank represents the customer to buy goods from a third party, the murabahah sale and purchase contract must be done after the goods, in principle, belong to the bank. Always happens wakalah contract before the murabahah contract because the wakalah contract will end when the customer hands over the items purchased at the bank and accelerates the disbursement process and facilitates the customer, so that after the goods are received by the bank there will be a murabahah contract. Whereas according to Law Number 21 of 2008 concerning Islamic Banking Article 19 number 1 letter o, that banks may function as Trustees based on the Wakalah Agreement.

The foundation of sharia law about wakalah al-Qur'an Surah Al-Kahf: 19. "So we woke them up, so that their fellow men inquired, said one of them: how long did we stay here? Their answer: one day or half a day. They say: Your Lord knows better, how long you are silent (here). Therefore, send one of you (go) to the city with this silver money, and let him see which food is cleaner, then bring it here for your sustenance and let him be gentle and do not tell anyone about you. The Pillars of Murabahah bil Wakalah are:

a) Seller $\left(b a^{\prime} i\right)$

b) Buyer (musytary)

c) Purchased goods (commodities)

d) Price (tsaman) consisting of the purchase price of the profit margin and selling price.

e) Actors of contract, namely the muwakil (power of attorney) is the party that gives power to the other party, and the representative (proxy) is the party authorized.

f) The object of the contract, namely taukil (the authorized object).

g) Shighah, namely Ijab and Qabul.

Whereas the conditions for Murabahah bil Wakalah are namely:

a) Must be used for lawful goods, unclean goods are not legally traded and goods are not state prohibitions,

b) The seller notifies the cost of capital to the customer,

c) The first contract must be valid in accordance with the stipulated rules,

d) The contract must be free of usury,

e) The seller must explain to the buyer if there is a defect in the goods after the purchase,

f) The seller must submit all matters relating to the purchase, for example if the purchase is made in debt

g) The object of the contract must be clear and can be represented

h) Not contrary to Islamic law.

Overview of the Systematics of the Process of the Murabahah Purchase Agreement is as follows: 
SKEMA MURABAHAH

Aplikasi Teknis Pembiayaan Perbankan dengan Akad Wakalah

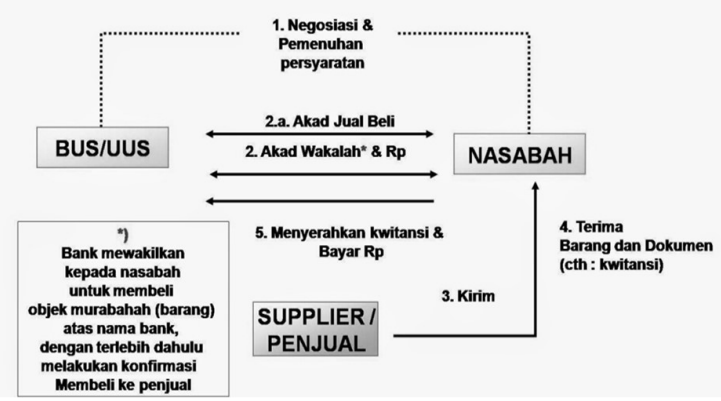

\section{F. Conclusion}

According to the Sharia Banking Act Number 1 of 2008 Article 1 paragraph 13, a contract is a written agreement between a Sharia Bank and a Sharia Business Unit with another party which contains the obligation for parties according to sharia principles. Contract definition is a legal relationship between parties that gives rise to rights and obligations exchanged by the parties. Agreement terminology is the event a person promises to another person or somewhere two people promise each other to do something or plan. These three concepts are equated in linguistic and juridical reviews, as well as bringing together rights and obligations between parties who are religious, and all three are both binding concepts in business law. The difference between the three concepts is that the agreement is different from the contract according to the science of jurisprudence, the agreement is different from the agreement according to business law, but the difference is only in terms that use it.

Legal and sharia review of the murabahah bil wakalah agreement, that legally and sharia murabahah agreement is legalized and legal and shari'ah contracts are also legalized. However, if the murabahah bil wakalah contract is unclear between which two contracts are used, then there is uncertainty (gharar), the law of the two contracts is given priority. Or whether the wakalah relies on murabahah or vice versa, or the murabahah contract that requires wakalah or wakalah which requires the existence of murabahah, then the second transaction of the contract, meaning the murabahah bil wakalah transaction is forbidden. But if the two contracts can be clear (not gharar) and separate (which one should take precedence), then one transaction with two contracts is permitted, for example murabahah bil wakalah transaction, by means of the wakalah contract, then the murabahah contract, then like this the transaction is legal.

\section{BIBLIOGRAPHY}

\section{Books}

Al-Jauziyyah, Ibn al-Qayyim, I'lam alMuwaqqi'in Rab an Rabb alaminAlamin. Dammam: Dar Ibn alJauzi, 1423 H. vol. 5

Anshori, Abdul Gofur, Sharia Banking Law. Bandung: Refika Aditama, 2011.

Antonio, Muhammad Sayfai'i, Islamic Bank from Theory to Practice. Jakarta: Gema Insani Press, 2001.

Antonio, Muhammad Syafi'i, Islamic Bank from Theory to Practice. Jakarta: Rajawali Press 2003.

Arifin, Zainul, Basics of Sharia Bank Management. Jakarta: Alvabet Library, 2006.

Ascarya, Akad and Sharia Bank Products. Jakarta: PT RajaGrafindo persada, 2008.

Ash-Shawi, Shalah and Al-Muslih, Abdullah, Jurisprudence of Islamic Economics, Dr. Muslim. Riyad: Dar Sunnah, 2011. 
Asiyah, Binti Nur, Mini Islamic Bank Practice 2. Tulungagung: IAIN Tulungagung, 2014.

Asser, C., Assessment of Dutch Civil Law. Jakarta: Dian Rakyat, 2001.

Badrulzaman, Mariam Darus, Bank Credit Agreement. Jakarta: PT. Citra Aditya Abadi, 2012.

Burhan, Bungin, Qualitative Research Methodology. Jakarta: Raja Grafindo Persada, 2014.

Darmabrata, Wahyono, Civil Law (Discussion of the Principles of the Hokum Civil). Jakarta: CV. Gitama Jaya, 2014.

Hamidi. Qualitative research method. Malang: University of Muhammadiyah Malang, 2004.

Harahap, Yahya, Aspects of Agreement Law. Bandung: Alumni, 1986.

Hernoko, Agus Yudha, Agreement Law: Principle of Proportionality in Commercial Contracts. Yogyakarta: Laks Bang Mediatama, 2010.

Hilman, Faith, et al., Future Islamic Banking. Jakarta: Senayan Abadi Publishing, 2013.

Ibrahim, Johannes, Credit Card: The Dilemma Between Contracts and Crime. Jakarta: Refika, 2014.

Imam Abu Daud, Sulaiman ibn al-Ash'ats ibn Ishaq ibn Bisyr ibn Syaddad ibn 'Amr ibn' Imran, Abu Dawud al-Azdi as-Sijistani, Shahih Sunan Abu Daud. Lebanon: Dar alHadith, t.th.

Imam Ahmad, Ahmad bin Muhammad ibn Hanbal ibn Hilal Ash Syaibani, Musnad Ahmad bin Hambal. Riyad: Dar al-Hadith, t.th.

Imam Al-Kasani, Bada'i as-Sana'i, (Cairo: Maktabah Ilmiyah, t.th.

Imam Baihaqi, Abu Bakr Ahmad ibn AlHusayn ibn Ali ibn Musa AlKhusrauijrdi Al-Khurasani AlBaihaqi, Sunan al-Kubra, sunan alBaihaqi. Lebanon: Maktabah Wakfiyah, t.th.
Imam Bukhari, Abu Abdullah Muhammad ibn Ismail Al-Bukhari bin Ibrahim bin Al-Mughirah bin Bardizbah, Imam al-Bukhari, Sahih Bukhari. Bairut: Darul Ibn Kathir alYammah, t.th.

Imam Ibn Hibban, Muhammad bin Hibban bin Ahmad Abu Hatim al Butsy at Tamimy, Shahih Ibn Hibban. Cairo: Dar ilmi, t.th.

Imam Ibn Majah, Abu 'Abdillah Muhammad bin Yazid bin" Abdillah bin Majah al-Qazwini., Al-Sunan Ibn Majah. Egypt: Maktabah al-Sunnah, t.th.

Imam Malik, Abdullah Malik ibn Anas ibn Malik ibn Abi Amir ibn Amr ibn al-Haris ibn Gaiman ibn Husail ibn Amr ibn al-Haris al-Asbahi alMadani, Al-Mua'tha 'Imam Malik. Beirut: Dar Fikri, t.th.

Imam Nasa'i, Abu 'Abdirrahman ahmad bin su'aib bin ali bin bahr bin sinan bin dinar an-Nasai al-Kurasani., $A l$ Sunan al-Nasa'i. Cairo: Dar Ilmi, t.th.

Imam Suprayogo and Tobroni. SocialReligion Research Methodology. Bandung: Teenager Rosdakarya, 2012.

Imam Tarmizi, Abu 'Isa Muhammad bin a isa bin surrah al-Turmudzi Ibn Musa Ibn Adh-Dhahak Al-Sulami Al-Bughi Al-Tirmidhi, Al-Sunan Al-Tirmizi. Lebanon: Dar alHadith, t.th.

Islam, Center for Legal Studies, Compilation of Sharia Economic Law. Jakarta: PPHIMM \& Kencana, 2009.

Karim, Adiwarman A., Islamic Bank Jurisprudence and Financial Analysis. Jakarta: Graha Grafindo, 2015.

Karim, Adiwarman A., Islamic Bank; Fiqh and Financial Analysis. Jakarta: Raja Grafindo Persada, 2010.

Karnaen Perwataatmaja and Muhammad Syafe'i Antonio, What and How 
are Islamic Banks. Jakarta: Dana Bhakti Prima Yasa, 1992.

Kasmir, Banking Management. Jakarta: PT. Raja Grafindo Persada, 211.

Lathif, Ah. Azharuddin, Concept and Application of Murabahah Agreement to Sharia Banking in Indonesia. Jakarta: Books Not Published.

M. Suyanto, Business and Investment in the Sharia System. Yogyakarta: Atma Jaya University, 2009.

Moleong, Lexy J., Qualitative Research Methodology. Bandung: Teenager Rosdakarya, 2011.

Muhajir, Neong., Qualitative Research Methodology. Yogyakarta: Rake Sarasin, 1998.

Muhammad, Islamic Bank Financing Management. Yogyakarta: UPP STIM YKPN, 2015.

Muhammad, Islamic Bank Management. Belbuk. Com, 2002.

Muhammad, Syari'ah Bank Management. Yogyakarta: UPP STIM YKPN, 2012.

Mujahidin, Ahmad, Sharia Banking Law. Jakarta: PT. Rajawali Press, 2017.

Mujahidin, Ahmad, Sharia Banking Law. Jakarta: Rajawali Press PT. Raja Grafindo, 2016.

Mulyana, Dedy. Qualitative Research Methodology. Bandung: Youth Rosdakarya, 2015.

Nawawi, Hadari., Research Method in the Social Field. Yogyakarta: Gajah Mada University Press, 2015.

Nawawi, Ismail, Muamalah Fiqh (Economic, Business and Social Law). Surabaya: Putra Media Nusantara, 2010.

Nazir, Muhammad, Research Methodology. Jakata: Ghalia Indonesia, 1997.

Putong, Iskandar., Qualitative Research Methods: Applications for Educational Research, Law, Economics \& Management, Social Sciences, Humanities, Politics,
Religion and Philosophy. Jakarta: Gaung Persada, 2010

RI Religion, Department, Al-Qur'an and Translation. Semarang: Toha Putra, 2015.

Rusyd, Ibnu, Bidayah al-Mujtahid. Lebanon: Darul Kutub Ilmiyah, t.th.

Satrio, Aji, Juridical Analysis Law of Bank Agreements. Jakarta: FHUI, 2009.

Setiawan, Principles of Engagement Law. Jakarta: Bina Cipta, 2001.

Subekti A, Agreement Law in Indonesia. Jakarta: Yutisia Library, 2012.

Subekti B, Principles of Civil Law. Jakarta: Intermasa, 2011.

Sutedi, Adrian, Islamic Banking Overview of Several Legal Aspects. Bogor: Ghalia Indonesia, 2011.

Sutopo, HB., Introduction to Qualitative Research. Surakarta: Sebelas Maret University Press, 2004.

Yunus, Mahmud, Tafsir Qur'an Karim. Jakarta: PT. Hidakarya Agung, t.th.

\section{Ilmiyah Journal and Work}

Aryanti, Yosi, Multi Akad (Al-Uqud AlMurakkabah) in Islamic Banking Perspective of Muamalah Fiqh. Syari'ah Scientific Journal, Volume 15, Number 2, July-December, 2016.

Chikmah, Achasih Nur, Comparative Analysis of Conventional Bank Credit System With Islamic Bank Financing in Micro, Small and Medium Enterprises. Unesa Student Journal, Edsisi 1, 2017.

Fitriani, Ifa Latifa, Collateral and Collateral in Islamic Bank Financing and Conventional Bank Loans. Journal of Law \& Development, Edsis 47, 2017.

Indriana, Dewi and Zuhroh, Idah, Analysis of the Quality of Islamic Banking Financing for 2006-2010. Journal of Development Economics Journal, 10th Edition, 2012.

Kusumawati, Nidaa Nazaahah., Nuryartono, Nunung., Beik, Irfan Syauqi. Analysis of Financing and 
Credit in the Construction Sector in Indonesia: Study of Islamic and Conventional Banking (Analysis of Financing and Credit on Indonesian Sector Construction: Study of Islamic and Conventional Banking) . Journal of Economic and Development Policy, Edsisi 6, 2017.

Nofinawati, Development of Islamic Banking in Indonesia. Juris Volume 14, Number 2. JulyDecember 2015.

Pato, Saduldyn, Analysis of Provision of Micro Loans to Bank Syariah Mandiri, Manado Branch. EMBA Journal, Issue 1, 2013.

Rachmawati, Eka Nuraini \& Ab Ghani, Ab Mumin bin, Sale and Purchase Agreement in the Jurisprudence and Practice Perspective in the Indonesian Capital Market. Alalahis Vol. XII, No. 4, December 2015.

Rangkuti, Tavitri, Effects of Credit Analysis on Problematic Financing (Bad Credit) at the Artha Madani Syariah People Financing Bank Cikarang, West Java. Journal of Transparency, Issue 1, 2018.

Sari, Nurma, Comparative Analysis of House Ownership Financing in Conventional and Islamic Banks (Case Study at Bank Mandiri and BRI Syari'ah). Al-Maslahah Journal, Issue 13, 2017.

Supriyadi, Agus and Kartikasari, Dwi, Relationship of Credit Analysis of the Quality of Kpr Financing at Pt $X y z$ Batam Branch. Journal of Accounting, Economics and Business Management, Issue 3, 2015.

Syafe'i, Rachmat, Multi-Akad Transaction in Jurisprudence Perspective (Paper presented at the Legal Discussion with the theme "MultiCovenant in the Contemporary Syari'ah Economic Perspective" held at the West Java Religious
High Court, Thursday February 22, 2018.

Wangsawidjaja, A., Islamic Bank Financing. Jakarta: Gramedia Main Library, 2012.

\section{Thesis / Dissertation}

Kurneawati, Analysis of Accounting Treatment for Murabahah Receivables at PT. Bank BRI Syariah KCI Gubeng Surabaya. Surabya: Not Published, 2011.

Nurhadi, Legal Analysis of Engagement Agreement for Financing Murabahah Clause Bil Wakalah Number. 090 / Mrbh / Pkb / V / 2016 Bank Rakyat Indonesia Syari'ah. Pekanbaru: UIR Postgraduate Study in Law, 2016.

Roifah, Azzifathur, Implementation of Murabahah Financing Bil Wakalah As an Effort to Improve the Economy, Cattle Breeders at the National Lks Sendang Branch. Tulungagung: Islamic Banking Department Faculty of Islamic Economics and Business State Islamic Institute (IAIN) Tulungagung 2015.

Wildantyo, Yassar, Application for the Murabahah Agreement Bil Wakalah in Micro Financing at BRI Syari'ah Kcp Kudus. Islamic Banking Faculty of Economics and Islamic Business UIN Walisongo Semarang, 2016.

\section{Legislation and Law}

The Fatwa of the National Syari'ah Council No: 04 / DSN-MUI / Iv / 2000 concerning Murabahah

Fatwa of the National Syari'ah Council No: 10 / DSN-MUI / Iv / 2000 concerning Wakalah

Article 2 paragraph 25 of Act Number 21 of 2008 concerning Sharia Banking.

Law Number. 21 of 2008 concerning Sharia Banking

Civil Code Law. Book I Chapter I About Engagement 
Law No. 10 of 1998 concerning Banking credit

Law Number 21 of 2008 concerning Islamic Banking Article 19 number 1 letter d.

Sharia Banking Act No. 21 of 2008 Article 1 paragraph 1 